\title{
Unequal Itineraries for Graduates: A Typology of Entrance into Labour Market
}

\author{
Ana Paula Marques \\ Associate Professor, PhD of Sociology, (University of Minho/Portugal), \\ Senior Researcher in the Interdisciplinary Centre of Social Sciences (CICS. NOVA. UMinho) \\ amarques@ics.uminho.pt
}

\section{Doi:10.5901/ajis.2015.v4n1s2p19}

\section{Abstract}

In the transition from higher education to the labour market, the critical correspondence between qualification and first job, as well as precariousness and/ or unemployment experiences has been a crucial topic of understanding of labour market as one of the main facets of social and socio-economic insecurity and risks in contemporary European societies. In this paper we intend to contribute to the debate on unpredictable itineraries of professional integration of graduates from Higher Education which revels simultaneously and differently patterns of employability and professionalization segments. By mobilising some of the research outcomes of the projects lead by us, it is our purpose to cross contributions from the sociology of professions and employment in order to analyse the main social forms of entrance into labour markets. Based on the articulation of two axes, namely, social regulation and professional mobility, which are structured in a continuum in abstract terms, four "ideal-types" of social forms were defined: professional markets, internal markets, transitional markets and secondary markets (in neoclassic terms). In that sense, main exploratory analytic dimensions were mobilised on four levels: symbolic (recognition and the importance of academic title, identity and integration), cognitive (expertise and professional experience), social-political (dominant contractual status, market independency) and organizational (career/hierarchical position).

Keywords: Graduates, Labour market, Social regulation, Career mobility.

\section{Introduction}

It is common knowledge that the last decades have been deeply influenced by crucial changes in globalised labour market. These changes have led, to a greater or lesser extent and depending on the specific country, to the increased flexibility and precariousness of labour market, to the segmentation of the workforce and the development of "atypical" forms of employment as opposed to the dominant model in the wage-based post World War II period. Until then, the typical relationship was based on employment stability by contractual basis which underlies the collective agreement of work and compliance of criteria such as: i) the durability of the employment relationship, ii) the uniqueness of the employer and, belonging to an organized service; iii) working full-time with an equivalent wage (Foucarde, 1992). It defined therefore, the profile of what has come to be socially and legally designated as wage "typical" employment, setting the standard of employment (permanent, full-time and social protection). In this sense, they are considered "atypical" situations all of which do not check one or other or all of those criteria. Overall, these atypical forms of work can range from simple undeclared activities (in the form of "concealed employment" which, although not illegal in itself, is not declared to one or more administrative authorities who should be aware of it and that, in this way, is absent from regulation and taxation or reduction of social security benefits) forms of temporary, full time or part-time contracts (Célestin, 2000).

While it is true that the results of several researches seem to point to some different occupational transitions that include different working conditions and heterogeneous statutes - which reveal, on the one hand, the growth achieved in the search for graduates by business employers (Diana \&Marques, 2014; Marques, 2010, 2007) - it is also true that employers tend to focus on recruitment arrangements and worker management close to a quantitative flexibilization by the increased mobilization of employment forms that go beyond the "typical norm". Therefore, it is possible to identify three major trends that affect graduates' professional transitions.

First of all, the recent transformation in educational and productive systems has changed the practices and references associated with the processes of "entry into adulthood" (Galland, 1997, 1996, 1984 ) or professional transition of youths, especially the graduates who tend to have nonlinear trajectories (e. g. training, employment, unemployment and inactivity) affecting the transformation of traditional representations of employment and occupation. 
Secondly, we are witnessing a phenomena regarding the extension in the time of studies (initial training and lifelong learning) as well as intermediate and precarious positions until the achievement of a stable position in the labour market (Marques, 2006). The duration of these processes becomes itself a structuring factor of occupational transition, defined by the diversity of situations, statutes or conditions (e. g. fellow researcher, trainee, independent worker) that prevail in recurrent situations of vulnerability and precariousness in relation to employment.

Finally, these practices and references related to professional transition extend through non-linearity, resulting in a desynchronization of the various axes of professional emancipation, personal and family life.

These trends have led modern societies to make changes in the labour market processes or towards a transitional labour market (Schmid, 2000), in which the demarcation lines between work, leisure, education and care have been blurred, leading to increased mobility and flexibility, de-standardization of the course of life and to an overall focus on employability.

Taking into consideration this background, the research reported here explores main traits of transformation of the educational contexts and labour markets, in order to bring light to the social structural conditions in which young graduates are been enrolled in unpredictable professional itineraries. Therefore, we will start by presenting the main traits of transformation of the educational contexts. Next, on a second topic, we will perform a reflection on how those professional itineraries reveal simultaneously and differently patterns of employability and professionalization segments. Finally, a proposal to systematise the main social forms of access to employment/profession is presented, assuming two analytical axes in its conceptualisation: 1) social regulation and setting of professional jurisdictions; and 2) organisational and professional mobility. This is a typological essay, which identifies four "ideal types" of important labour markets for graduates: professional markets, internal markets, transitional markets and secondary markets (neoclassical sense).

\section{Expansion of Higher Education: Shifts and Tensions}

The expansion of higher education and the gradual increase of graduates have been followed by empirical evidence that points to the possibility of obtaining a qualified job linked to higher education levels (Diana \& Marques, 2014; Tomlison, 2013, 2009; Smyher et al. , 2001; lannelli \& Soro Bonmatí, 2003; Machin \& MacNally, 2007). However, access to the labour market does not present itself as being uniform and stable to most young adults.

Until now, public policies have pursued certain objectives aiming to influence the education system to enlarge and to improve the opportunities for professional regulated education, whether at secondary and post-secondary levels (with the reintroduction of technical and technological teaching in secondary school) and in higher education, so as to carry out the demands of employability and internationalization among others, envisaged by the Bologna Declaration. It is expected that it will be possible, then, to identify politically relevant scientific areas (and therefore eligible for accruing public funding), to increase student mobility within Europe, to set mutually recognizable diplomas as soon as a degree equivalence is ensured, and also to give more dynamism to scientific and academic networks in the European context.

However, there are different approaches to this problem, according to the countries involved (Tomlison, 2012, Teichler, 2007; Jobert, Marry \& Tanguy, 1995; Hannan et al. 1999, Muller \& Gangl, 2003), as most of them are currently confronted with quite similar problems and challenges concerning the more or less predictable effects of these changes in higher education. These transformations are attached primarily to the extent of time spent in the education system (initial and life-long training), which is linked to a relatively recent trend to the feminization of university ranks, in spite of a minor presence in engineering and technology. Besides, it is necessary to consider the consequences, a few of them already predictable while others still latent, related with school massification and with the diversification of the courses offered by the education system. As a matter of fact, while providing the entry of student publics that form a more and more heterogeneous universe regarding their social origins, school trajectories, vocations and professional careers, universities must consider not only their curricula and pedagogic practices, but also the professionalization, specialization and research paths involved in their activities.

The organization and structuring of the education system ranks, as well as the devices to gain access to the labour market, presuppose the access to university to relevant information regarding teaching itself and their students' professional future. This will allow them to identify cognitive thinking, process evaluation, relationship factors, and other competencies considered nuclear for designing courses and their curricula. Such knowledge, necessary to all subjects, should give clear directions and take into consideration not only the changes occurring in traditional jobs, but also the mapping of new professions whose frontiers seem more and more imprecise and broadening.

Relationships between academic training and the labour market have been central in (political, educational and scientific) public debates in the last decades. The choice of the approaches privileged in these debates is largely 
dependent on the political agenda of the most advanced economies (cf. Pedroso et al, 2005). Many of those approaches have been rapidly changing. Illustrative of this is the sequence of priorities ascribed to during the last decades (Teichler, 2007): i) to the contribution of higher education for economic growth; ii) to the dangers of "over-qualification" and of the disarticulation between supply and demand; iii) to the diversity of education and to job opportunities; iv) to the growing incidence of graduate unemployment and to the precariousness of their work and employment conditions; v) to the emphasis on training "key-qualifications"; vi) and finally, to the trend towards the globalization of the young graduates' labour market.

\section{Professional Transitions, Segmentation and Precariousness}

As a social problem with diverse manifestations, the contexts and kinds of professional transitions currently analysed convene other explicative factors in terms of changes in the productive and employment systems. One of them concerns the difficulties of professional insertion that affect graduates, and not just those deprived of academic qualification. Moreover, the relative depreciation of initial training, linked to the "diploma inflation" effect and its correlative devaluation presupposes strategies of quick recycling of "disqualified" symbolic capitals, with particular incidence on the "social capitals" held by candidates to their first job. It is after all, well known that access to the "first job" depends more on the candidate's personal and family network efficiency. Likewise, we should be aware of the trend for a decreasing correspondence between the diploma and the profile required by available jobs, which may explain to a large extent, the growing distortion of students' representations and expectations of forthcoming complex and extended (time and space) trajectories.

In fact, regarding the current constraints of flexibility and globalization of the labour market, most companies expose social groups who have invested in their professional and academic training to growing precariousness. If these are used to present advantages over those who were deprived of such resources, in the current context of deep transformation of the productive and educational systems, employment relationships become much more volatile and non-prescriptive of the conduct of social actors. Certain references of a salary-based society have been weakened, such as those of stability and predictability of professional trajectories, at least to qualified workers with changes in employment situations and conditions, and heterogeneous statuses (e. g. fellow researcher, trainee, part-time, independent worker/task worker). It is known that uncertainty and the instability of the contractual relationship, despite the diverse modalities it may assume according to each country, affect almost an entire generation of men and women and young adults with or without diplomas.

Therefore, today, the focus behind this discussion is on knowing to what extent the professional transition of young graduates has been presenting (in)visibility contours in the labour market, and what its main challenges and (new) employment risks are. Attempts to answer this will enable us to better understand patterns of transition in the labour market, profiles and professionalization areas and demonstrations of skills and relational insights that reinforce the thesis of interchangeability of academic training in contemporary societies. Also, when completing the mapping of these (in)visibility boundaries of this process, it raises the issue of entrepreneurship and its implications towards new professional statutes and in reference to professional identity, particularly by the different leaders and social actors: responsible scholars, policy makers and all individual and collective actors involved in this area (Marques, 2013).

\section{Social Regulation and Professional Mobility: A Typology of Entrance into Labour Market}

\subsection{Research design information}

By mobilising some of the research outcomes of the projects lead by us, namely: "Meintegra" (Integrate me), "Percursos de inserção dos licenciados" (Integration paths of graduates) and "O potencial de empreendedorismo" (The entrepreneurship potential), it is our purpose to cross contributions from the sociology of professions and employment in order to analyse the main social forms of entrance into labour markets.

The first project, "Melntegra - Mercados e Estratégias de Inserção Profissional de Jovens Diplomados" (Integrate me - Markets and strategies of professional integration of young graduates), carried out between 2006-2007, involved several stages of research and followed three main thematic axes: 1) identification and characterisation of the strategies for professional integration; 2) identification of the practices of mobilisation of the skills by the employers in the framework 
of a flexible management of labour; 3) understanding and explaining the structural organisational resistances/ opportunities for innovation and competitiveness1.

The project entitled "Percursos de inserção de licenciados: relações objetivas e subjetivas com o trabalho" (Integration paths of graduates: objective and subjective relations with work) aimed at analysing and interpreting the relations with work in the process of professional transition of graduates during the year 2010/20112.

Finally, the "O potencial de empreendedorismo na Universidade do Minho" (The entrepreneurship potential in the University of Minho) (2010-2012) project, carried out in the framework of the Laboratório Melntegra spin-off and in the Research Centre for the Social Sciences (CICS/UM), had as main goal to study the potential entrepreneur among the young graduates in the University of Minho3.

\subsection{Main research findings}

One of the main dimensions concerns the condition of dependence or independence in the contractual relation of the graduates in a labour context. It is important to highlight that the wage earning and the experiences of unemployment transform the real conditions of exercising a profession. In that sense, Evetts $(2012,2010)$ and Kuhlmann $(2012)$ are unanimous in the diagnosis of the changes in autonomy and independence as foundations of authority of the certified knowledge, the relations of trust and the professional ethos that the several professional groups face in the contemporary world.

Considering our research outcomes, we conclude that the majority of graduates are in a full time employment situation, i. e. , as a wage earner ("Melntegra": 71\%; "Percursos de inserção dos licenciados": 89. 3\%; "O potencial de empreendedorismo": 66. 8\%). Likewise, if the unemployment percentages are not very expressive at the time, considering our outcomes, the truth is that a growing importance of the phenomenon of "unemployment of insertion" or "standstill in training" of many graduates is verified. This means that the proliferation of the statuses of a research scholarship holder, student or in professional training, among other, without giving a normative and regulatory framework of the labour relation, contributes to making the worsening of the situation of "non-effective professional integration" more visible. Thus, the relative weight of this reality presents the following values: "Melntegra": 8\%; "Percursos de inserção dos licenciados": 10. 3\%; "O potencial de empreendedorismo": 10. 8\%.

In what concerns the exercise of a profession as self-employed (self-employed worker/entrepreneur), the records obtained in our research are the following ones: "Melntegra": 12\%; "Percursos de inserção de diplomados: 10. 4\%"; "O potencial de empreendedorismo": 12 . 4\%. It is known that there are many risks associated with professional paths based on autonomous projects or entrepreneurial careers. These imply individualisation and externalisation of the production costs and all the consequences of contractual instability that come from there, as well as ruptures and imprecisions of borders of professional activity and dismantling of the axes of financial, family and affective emancipation (Marques, 2013).

In another analysis perspective, the enrolment of unpredictable and unequal itineraries facing the labour market passes through these embedding, more and more, generalised practices of visible quantitative flexibility in the use of types of employment, which are different from the "typical norm", such as mentioned before. According to our results, the most common statuses pass through the existence of shorted-term contracts (fixed-term or of indefinite duration),

\footnotetext{
1 To write this paper, we will use only the information collected through the questionnaire applied to the graduates of University of Minho located at north of Portugal, who have completed their graduate degrees, in the 2004/2005 academic year ( $N=464)$. For a more profound look of the main outcomes, cf. Melntegra report at http://repositorium.sdum.uminho.pt/bitstream/1822/8633/1/Melntegra\%20\%20RepositoriUM.pdf.

2 In total, an extensive survey was applied to a sample of 1004 graduates from all the degree courses offered in the Universidade Nova de Lisboa (40.5\%) and Universidade de Lisboa (59.5\%), both from Portugal, and who have completed their graduate degrees in the 2004/2005 academic year. This project (PTDC/CS-SOC/098459/2008) have presented outcomes of more comprehensive studies that go beyond the purposes of the current paper. However, the fact that we are part of the research team, allows us, for analytical purposes, to study in depth and oppose empirical evidences collected in that research, in order to reinforce the development of the arguments explained in this article.

3 The online survey was applied to a universe of 1,419 graduates from the University of Minho, who completed the course since 2002 to 2008, from 43 courses that have been grouped into six tracks, according to the National Classification of Education and Training Areas (2008) such as: "Education", "Arts and Humanities," "Social Sciences, Business and Law", "Science, Mathematics and Computer Science", "Engineering, Manufacturing and Construction", "Health and Social Protection." The sample resulted in a 20\% quota share, totaling 283 valid surveys.
} 
temporary, traineeship and part-time contracts: "Melntegra": 73\%; "Percursos de inserção de diplomados": 52. 3\%).

Besides these objective practices of labour and social precariousness, we should take into account the dimensions of subjectivity associated with the experiences and different representations by graduates. In the scope of the "Melntegra" project, it is visible the idea that the academic degree is one of the essential requirements to obtaining a position of success in society. There is the perception that the diploma no longer protects its holder from unemployment, in the same way that certified knowledge and expertise do not end there. The graduate is responsible for investing in further education and in the acquisition of other skills to determine his/her professional success. Likewise, entrepreneurship starts to be seen as a possible solution against unemployment, which reaches more and more the group of graduates. In fact, in the course of the interviews carried out for the "O Potencial de Empreendedorismo" project, the option for selfemployment could be understood through the following testimony: "I could give many reasons to go forward, but none of them is the matter of employability. I really like it, ok (...) I am not able to teach, but I am able to do anything else, I have talent for that (...)". (E2, male, 29 years old, Biology/Geology Teaching). Still reinforcing the importance of the diploma and its relativisation by the simultaneous demands of innovation and risk, note the following quote: "I decided to create a company of environmental engineering services due to my education and the knowledge that I have in this area (...) Usually, entrepreneurship appears when someone has knowledge on a certain area, probably no one creates a company in an area that he/she knows nothing about, otherwise it will fail, but that might not happen... but it has strong probabilities" (E8, male, 30 years old, Environmental Engineering). In opposition, the reason that prevails in the following professional options is necessity: "For example, I would like to open an ATL [after-school recreation centre] or a day care. To begin with, I really like children... and I think it's harder to get a job (...), and I see, now that I am having a child, that it is harder to get, for example, a day care vacancy" (E3, female, 29 years old, Sociology); "My business sector is clothing, in other words, the creation of a clothing range (...). We will invest in this project because it does not demand a high investment (...). It is a small project, nothing new... We are going to try something and see if it works out (E7, female, 30 years old, Education)".

In fact, these testimonies reveal important segmentations of professional trajectories, considering both the scientific areas followed by the graduates and the gender. Several studies reinforce exactly the heterogeneity of the statuses and the segmentations assumed by the labour market in terms of gender, type of degree or school qualifications, age, among other (Marques \& Alves, 2010; Gonçalves, 2009). This heterogeneity of statuses and professional segmentations has consequences in the perception of daily work, in the anticipation of careers and in the projection of the future.

\subsection{A typology of entrance into labour market}

Based on previous contributions, the flexibility of labour relations configures the existence of markets endowed with greater or lesser social regulation and/or mobility, which always expresses unequal positions in professional and organisational careers, as well as in the practices of human resources management and specific contexts of socialisation. In this sense, the holders of academic titles stand out, when, in the access to the profession, are confronted with deregulated markets, mainly those peripheral or secondary, although requiring technical and scientific professional performances. In this situation, we are assembling all forms of internships/traineeships, underemployment and contractualisation through "false green receipts", which is based on the exteriorisation of the protection of social rights and guarantees in the individual and not in the organisation itself.

Likewise, we can also notice the importance of transitional markets along this segment of graduate labour, in part as a result of the tendency for flexibility and mobility of individuals. In fact, the labour markets are no longer predetermined paths, formatted and fixed beforehand, given the turmoil that affects the decisions of institutional leaders faced with external (e. g. technologies, business restructuring, demographic cycles) and internal (e. g. family exchanges, individual reorientations) circumstances. The constant exits and re-entries, based on a high inter organisational professional mobility at a (trans)national level, constitute traits of the normal functioning of the labour market. With a strong component of a normative/political character, the active policies of employment contribute directly to the shaping of this type of market, which is based on the assumption of targeting its effectiveness from the adjustment to the best individual solutions.

Therefore, the articulation of two axes, namely, social regulation and professional mobility have led us to put forward four "ideal-types" of social forms of entrance into labour market: professional markets, internal markets, transitional markets and secondary markets (in neoclassic terms). In their definition main analytic dimensions were mobilised on four levels: symbolic (recognition and the importance of academic title, identity and integration), cognitive 
(expertise and professional experience), social-political (dominant contractual status, market independency) and organizational (career/hierarchical position). This analytic proposal is to account for the diversity of social forms that enclose the logical and operational structures of those labour markets in which graduates are currently in circulation. For each of those social forms are presented characteristics that allow their definition and distinction, lacking, however, further work based on future in-depth research.

\section{Final Remarks}

The main trends of graduates' professional transition trajectories found in international researches are confirmed taking into consideration our research findings. The transition of young graduates into the labour market is constrained by cultural, structural and institutional factors at different levels (national and international) and influenced by the education and labour markets of each country. It is also worth remarking that even more important from a cross-national perspective, are the higher educational systems, namely their direct linkage to the labour market or the flexibility of pathways. In fact, the confrontation with the labour market, with the uncertainty and instability of the contractual relationship, despite the different forms that it can take according to the countries, reaches almost an entire generation of qualified (or not) young men and women. The effects of the extension in time and space of this process are manifested in the course of life and in its fundamental stages, in the distinct ways of managing incorporated resources and provisions, expressing margins of freedom contained in a given moment of the personal and collective history, but also by delimiting the field of possibility, the options still available to them.

The paper has presented an exploratory typology of social forms of access to the labour markets in the contemporary world, in order to resist to the homogenising and/or radicalised approaches on the deprofessionalisation/ disqualification trends of professional groups. Also, we intend to restore the complexity of the phenomena of labour markets. The conceptual deepening of these recompositions requires, in parallel, their validation with future empirical research. The translation of those analytical axes into research hypotheses will allow evaluating the analytical relevance with the substantive information about academic and professional paths and identity recomposition processes underway by higher education graduates.

\section{References}

Alves, Mariana G. (2007). A inserção profissional de diplomados de ensino superior numa perspectiva educativa: 0 caso da faculdade de Ciências e Tecnologia. Lisboa: Fundação Calouste Gulbenkian/ Fundação para a Ciência e Tecnologia.

Célestin, J. -B. (2000). As Novas Formas de Emprego Atípicas. Reflexões sobre o caso Francês, 23, Ministério do Trabalho e da Solidariedade/ Direcção Geral do Emprego e Formação Profissional e Comissão Interministerial para o Emprego.

Diana, V. \& Marques, A. P. (2014), Preparados para trabalhar? Lisboa: Maior Empregabilidade.

Evetts, J. (2012). Sociological analysis of the new profession-alism: knowledge and expertise in organizations, in T. Carvalho, R. Santiago and T. H. Caria (eds. ). Grupos Profissionais, profissionalismo e sociedade do conhecimento (13-27). Porto: Afrontamento.

Evetts, J. (2010). Reconnecting Professional Occupations with Professional Organizations: risks and opportunities, in L. Svensson, \& J. Evetts, (eds. ). Sociology of Professions: continental and anglo-saxon traditions (167-187). Goteborg: Bokforlaget Daidalos.

Foucarde, B. (1992). A evolução das situações de emprego particulares de 1945 a 1990. Travail et Emploi, 52.

Galland, O. (1984). Précarité et entrées dans la vie. Revue française de Sociologie, XXV, 49-66.

Galland, O. (1996). L'entrée dans la vie adulte en France. Bilan et perspectives sociologiques. Sociologie et Société, Vol. XXVIII (1), $37-$ 46.

Galland, O. (1997). La sociologie de la jeunesse. Paris: Armand Colin.

Gonçalves, C. M. , Menezes, I. , Martins, M. C. (2009). Transição para o trabalho dos licenciados da Universidade do Porto (20062007). Porto: Universidade do Porto.

lannelli, C. ; Soro Bonmatí, A. (2003). Transition pathways in Italy and Spain: different patterns, similar vulnerability?. in W. Müller and M. Gangl (eds) Transitions from Education to Work in Europe: The Integration of Youth into EU Labour Markets (pp. 212-250). Oxford: Oxford University Press.

Jobert, A. , Marry, C. and Tanguy, L. (1995). Éducation et Travail en Grande-Bretagne, Allemagne et Italie. Paris: Armand Colin.

Kuhlmann, E. (2012). Professionalism matters: unpacking the knowledge-power nexus in healthcare governance. in T. Carvalho, R. Santiago e T. H. Caria (eds. ), Grupos Profissionais, profissionalismo e sociedade do conhecimento (151-162. ). Porto, Afrontamento.

Machin, St. ; McNally, S. (2007). Tertiary Education Systems and Labour Market. Tertiary Review, OCDE.

Marques, A. P. (2006). Entre o diploma e o emprego. A inserção profissional de jovens engenheiros. Porto: Afrontamento. 
Marques, A. P. (2007). Melntegra - Mercados e estratégias de inserção profissional. Licenciados versus empresas da Região Norte. Relatório final. Universidade do Minho, URL: http: //hdl. handle. net/1822/8633.

Marques, A. P. (2010). 'Sacralização' do mercado de trabalho. Jovens diplomados sob o signo da precariedade. Revista Configurações 7, 65-89. Braga: CICS, Universidade do Minho.

Marques, A. P. (2013). Empregabilidade e (novos) riscos pro-fissionais Brandão, in A. M. Marques \& A. P. (Org. ) Jovens, Trabalho e Cidadania: Que Sentidos? (pp. 20-34), Ebook: CICS/ Univer-sidade do MinholSBN 978-989-96335-1-3. [Online]. Available: http: //www. lasics. uminho. pt/ojs/index. php/cics_ebooks/issue/view/123.

Marques, A. P. and Alves, M. G. (2010). Inserção profissional de graduados em Portugal. (Re)configurações teóricas e empíricas. V. N. Famalicão: Húmus.

Muller, W. and Gangl, M. (eds) (2003). Transitions from Education to Work in Europe: The Integration of Youth into EU Labour Markets. Oxford: Oxford University Press.

Schmid, G. (2000). Transitional Labour Markets. A New European Employment Strategy. In B. Marin, D. Meulders \& J. Snower (eds. ). Innovative Employment Initiatives. Aldershot: Ashgate.

Smithson, J. ; Lewis, S. and Guerreiro, M. das D. (1998). Percepções dos jovens sobre a insegurança no emprego e suas implicações no trabalho e na vida familiar. Sociologia - Problemas e Práticas, 27, pp. 97-133.

Smyher, E. et. al (2001). A Comparative Analysis of Transitions from Education to Work in Europe (CATEWE). Final Report. Bruxelas: Comissão Europeia.

Teichler, U. (2007). Careers of University Graduates. Views and Experiences in Comparative Perspectives. London: Springer

Tomlison, M. (2009). Higher Education and Graduate Employability, VDM Publishing.

Tomlison, M. (2012). Graduate employability: A Review of Conceptual ad Empirical Themes, Higher Education Policy, 25 (407-431).

Tomlison, M. (2013). Education, Work and Identity. Themes and Perspectives, Bloomsbury Academic. 
